\title{
Pengaruh Sikap, Motivasi dan Metode Mengajar Terhadap Hasil Belajar Mahasiswa Pada MKDU Bahasa Inggris Di politeknik Negeri Jember
}

Oleh;

Cholimatus Zuhro

\begin{abstract}
ABSTRAK
Penelitian ini dilatar belakangi oleh beberapa masalah yang terjadi di lapangan sepert 1. Sikap mahasiswa terhadap Mata kuliah dasar Umum Bahasa Inggris, 2. Pengaruh motivasi terhadap hasil belajar mahasiswa, 3. Kurangnya keikut sertaan mahasiswa dalam proses belajar mengakjar MKDU Bahasa Inggris, 4. Metode mengajar yang digunakan dosen belum dapat membangkitkan motivasi belajar Bahasa Inggris mahasiswa. Adapun tujuan penelitian ini adalah untuk mengetahui pengaruh sikap, motivasi dan metode mengajar terhadap hasil belajar mahasiswa pada Mata Kuliah dasar Umum Bahasa Inggris di Politeknik Negeri Jember. Jumlah sampel dalam penelitian ini adalah 80 mahasiswa dari berbagai jurusan yang ada di Politeknik Negeri Jember. Teknik pengambilan sampel dalam penelitian ini menggunakan teknik acak proporsional random sampling. Dari hasil penelitian ini dapat disimpulkan bahwa adanya pengaruh antara sikap, motivasi dan metode mengajar terhadap hasil belajar mahasiswa pada mata Kuliah dasar Umum Bahasa Inggris di Politeknik Negeri Jember. Besar pengaruh sikap belajar terhadap hasil belajar adalah $34 \%$, motivasi belajar terhadap hasil belajar adalah $31 \%$ dan metode mengajar terhadap hasil belajar adalah 5\%. Sisanya yaitu sebesar 30\% dipengaruhi oleh variabel lainnya seperti dari faktor fisiologis, faktor psikologis, faktor lingkungan keluarga, faktor lingkungan kampus dan faktor lingkungan masyarakat yang tidak diteliti dalam penelitian ini.
\end{abstract}




\section{Kata Kunci: Sikap belajar, Motivasi belajar, Metode mengajar, hasil belajar}

\section{Latar Belakang}

Bahasa berkaitan erat dengan kekuasaan dan politik (Kachru, 1986). Secara global Bahasa Inggris telah memenangkan kekuasaannya, yang tentunya tak dapat dipisahkan dari kekuasaan yang dimiliki Amerika Serikat pada saat ini, sebagai bahasa hegemon dunia yang menggunakan Bahasa Inggris sebagai bahasa negara. Dengan politik bahasa, Bahasa Inggris memiliki strategi dan prosesnya sendiri dalam melakukan kontrol kekuasaan.

Bahasa Inggris adalah alat komunikasi wajib untuk menghadapi pasar bebas khususnya AFTA 2015 yang sudah di depan mata. Globalisasi menyebabkan dunia menjadi semakin terasa tanpa ada batas antar Negara. Pengaruh globalisasi dirasakan di berbagai bidang kehidupan seperti kehidupan politik, ideologi, ekonomi, sosial budaya, pertahanan keamanan dan lain-lain. Memasuki era pasar bebas ASEAN (AFTA) 2015 menuntut setiap individu untuk mempersiapkan sumber daya yang handal terutama di bidang komunikasi.

Sesuai dengan pentingnya Bahasa Inggris dalam konteks global, Politeknik Negeri Jember telah mengalokasikan 2 dan 4 sks untuk mata kuliah Bahasa Inggris sebagai Mata Kuliah dasar Umum (MKDU). Bahasa Inggris merupakan mata kuliah penting sebagai dasar pendidikan dalam hampir semua program studi di perguruan tinggi. Dengan demikian pada beberapa perguruan tinggi, bahasa Inggris digolongkan sebagai mata kuliah umum (MKU). Di perguruan tinggi, bahasa Inggris merupakan bahasa asing pertama dan paling penting yang harus dikuasai oleh para anggota civitas akademika.

Untuk mencapai penguasaan bahasa Inggris ini, para mahasiswa, dalam hal ini mahasiswa yang bukan jurusan bahasa Inggris (non-English Department) diberikan mata kuliah dasar umum bahasa Inggris selama satu (1) semester dengan menggunakan silabus dan buku teks yang dirancang khusus berdasarkan disiplin ilmu tiap-tiap jurusan yang ada di fakultas. Di Politeknik Negeri Jember, pengajaran bahasa Inggris dilaksanakan selama kurun waktu satu semester dengan menggunakan metode langsung (Direct Method) yang mengajarkan bacaan khusus secara intensif..

Namun demikian, berdasarkan hasil evaluasi pelaksanaan bahasa Inggris di Politeknik Negeri Jember, diketahui bahwa kemampuan berbahasa Inggris sebagian besar mahasiswa masih tergolong rendah yaitu lebih dari 55\% mahasiswa yang mendapatkan nilai $\leq \mathrm{B}$. Diduga salah satu penyebab dari kemampuan bahasa Inggris yang demikian rendah itu adalah lingkungan belajar-mengajar yang kurang memberikan kesempatan kepada mahasiswa untuk berbahasa Inggris secara aktif. Dalam program perkuliahan bahasa Inggris reguler, pembelajaran keterampilan berbahasa speaking, listening, dan writing sangat tidak mungkin untuk dilaksanakan karena keterbatasan beban SKS mata kuliah. Selain itu, kecilnya jumlah SKS mata kuliah bahasa Inggris yaitu 2 sks (100 menit).

\section{Kajian Teoritis}

Sebagai latar belakang teoritis penelitian dalam bab ini dibahas tentang Pengertian Belajar, Motivasi, Mata Kuliah dasar Umum Bahasa Inggris dan Kebutuhan mahasiswa.

\section{1. Pengertian Belajar}

Banyak ahli yang telah mendefinisikan apa itu belajar . Di antaranya adalah definisi yang diungkapkan oleh :

1. Hilgard dan Bower, bukunya Theories of Learning ( 1975 ) mengemukakan . "Belajar berhubungan dengan perubahan tingkah laku seseorang terhadap sesuatu situasi tertentu yang disebabkan oleh pengalamannya yang berulang - ulang dalam situasi itu, di mana perubahan tingkah laku itu tidak dapat dijelaskan atau dasar kecenderungan respon pembawaan, kematangan, atau keadaan keadaan sesaat seseorang ( misalnya kelelahan, pengaruh obat dan sebagainya ) ,

2. Gagne, dalam bukunya The Conditions of Learning ( 1977 ) menyatakan bahwa : "Belajar terjadi apabila suatu situasi stimulus bersama dengan isi ingatan mempengaruhi siswa sedemikian rupa sehingga perbuatannya ( performance - nya ) berubah dari waktu sebelum ia mengalami 
situasi itu ke waktu sesudah ia mengalami situasi tadi ."

$\begin{array}{cccr}\text { Jadi bisa } & \text { disimpulkan bahwa } \\ \text { belajar } & \text { sebagai } & \text { karakteristik yang }\end{array}$ membedakan manusia dengan makhluk lain, merupakan aktivitas yang selalu dilakukan sepanjang hayat manusia, bahkan tiada hari tanpa belajar.

\section{2. Hasil Belajar Mahasiswa}

Hasil belajar tidak dapat dipisahkan dari berbuatan belajar, karena belajar merupakan suatu proses, sedangkan prestasi belajar adalah hasil dari proses pembelajaran tersebut. Bagi seorang anak belajar merupakan suatu kewajiban. Berhasil atau tidaknya seorang anak dalam pendidikan tergantung pada proses belajar yang dialami oleh anak tersebut.

bahwa $\begin{array}{rrr}\text { Winkel } & (1997: 193) & \text { berpendapat } \\ \text { belajar pada } & \text { manusia }\end{array}$ dapatdirumuskan sebagai suatu aktivitas mental atau psikis yang berlangsung dalam interaksi aktif dengan lingkungan, yang menghasilkan perubahan-perubahan dalam pengetahuan dan nilai sikap. Perubahan itu bersifat relatif konstan dan berbekas. Belajar tidak hanya dapat dilakukan di sekolah saja, namun dapat dilakukan dimana-mana, seperti di rumah ataupun dilingkungan masyarakat.

Hasil belajar adalah hasil dari adanya rencana dan pelaksanaan proses belajar, sehingga diperlukan informasiinformasi yang mendukung disertai dengan data yang obyektif dan memadai. Prestasi belajar masih menjadi tolak ukur kompetensi mahasiswa di bidang ilmunya.

\section{3. Faktor-Faktor yang Mempengaruhi Hasil Belajar}

Secara umum faktor-faktor yang memengaruhi hasil belajar dibedakan atas dua kategori, yaitu faktor internal dan faktor

\section{3. 1. Faktor internal}

Faktor internal adalah faktor-faktor yang berasal dari dalam diri individu dan dapat memengaruhi hasil belajar individu. Faktor-faktor internal ini meliputi faktor fisiologis dan psikologis.

\section{Faktor fisiologis}

Faktor-faktor fisiologis adalah faktor-faktor yang berhubungan dengan kondisi fisik individu. Faktor-faktor ini dibedakan menjadi dua macam. Pertama, keadaan jasmani. Keadaan jasmani pada umumnya sangat memengaruhi aktivitas belajar seseorang.

\section{Faktor psikologis}

Faktor-faktor psikologis adalah keadaan psikologis seseorang yang dapat memengaruhi proses belajar. Setiap manusia atau anak didik pada dasrnya memilki kondisi psikologis yang berbeda-beda, terutama dalam hal kadar, bukan dalam hal jenis. Tentunya perbedaan-perbedaan ini akan berpengaruh pada proses dan hasil belajarnya maisng-masing.

\section{a. Kecerdasan/intelegensi siswa}

Pada umumnya kecerdasan diartikan sebagai kemampuan psiko-fisik dalam mereaksi rangsangan atau menyesuaikan diri dengan lingkungan melalui cara yang tepat. Dengan demikian, kecerdasan bukan hanya berkaitan dengan kualitas otak saja, tetapi juga organ-organ tubuh yang lain. Kecerdasan merupakan faktor psikologis yang paling penting dalam proses belajar siswa, karena itu menenentukan kualitas belajar siswa. Semakin tinggi tingkat intelegensi seorang individu, semakin besar peluang individu tersebut meraih sukses dalam belajar. Sebaliknya, semakin rendah tingkat inteligensi individu, semakin sulit individu itu mencapai kesuksesan belajar.

\section{b. Motivasi}

Motivasi adalah salah satu faktor yang memengaruhi keefektifan kegiatan belajar siswa. Motivasilah yang mendorong siswa ingin melakukan kegiatan belajar. Para ahli psikologi mendefinisikan motivasi sebagai proses di dalam diri individu yang aktif, mendorong, memberikan arah, dan menjaga perilaku setiap saat (Slavin, 1994). Motivasi juga diartikan sebagai pengaruh kebutuhan-kebutuhan dan keinginan terhadap intensitas dan arah perilaku seseorang.

\section{c. Minat}

Secara sederhana, minat (interest) berarti kecenderungan dan kegairahan yang tinggi atau keinginan yang besar terhadap sesuatu. Menurut Reber (Syah, 2003), minat bukanlah istilah yang populer dalam 
psikologi disebabkan ketergantungannya terhadap berbagai faktor internal lainnya,

\section{d. Perhatian}

Perhatian adalah keaktifan jiwa yang dipertinggi, jiwa semata-mata tertuju kepada suatu obyek ataupun sekumpulan obyek (Slameto, 1991:58). Untuk dapat menjamin hasil belajar yang baik, maka siswa harus dihadapkan pada obyek-obyek yang dapat menarik perhatian siswa, bila tidak, maka perhatian siswa tidak akan terarah atau fokus pada obyek yang sedang dipelajari.

\section{e. Sikap}

Dalam proses belajar, sikap individu dapat memengaruhi keberhasilan proses belajarnya. Sikap adalah gejala internal yang berdimensi afektif berupa kecenderungan untuk mereaksi atau merespons dengan cara yang relatif tetap terhadap objek, orang, peristiwa dan sebagainya, baik secara positif maupun negatif (Syah, 2003).

\section{f. Bakat}

Faktor psikologis lain yang memengaruhi proses belajar adalah bakat. Secara umum, bakat (aptitude) didefinisikan sebagai kemampuan potensial yang dimiliki seseorang untuk mencapai keberhasilan pada masa yang akan datang (Syah, 2003). Berkaitan dengan belajar, Slavin (1994) mendefinisikan bakat sebagai kemampuan umum yang dimiliki seorang siswa untuk belajar.

\section{g. Kognitif dan Daya Nalar}

Pembahasan mengenai hal ini meliputi tiga hal, yakni persepsi, mengingat dan berpikir.Persepsi adalah penginderaan terhadap suatu kesan yang timbul dalam lingkungannya.Penginderaan itu di pengaruhi oleh pengalaman, kebiasaan, dan kebutuhan. Kemampuan mempersepsi antara siswa yang satu dengan siswa yang lain tidak sama meskipun mereka sama-sama dari sekolah yang sama.

\section{3. 2. Faktor-faktor eksternal}

Selain karakteristik siswa atau faktorfaktor endogen, faktor-faktor eksternal juga dapat memengaruhi proses belajar siswa. Dalam hal ini, Syah (2003) menjelaskan $\begin{array}{lcrr}\text { bahwa faktor } & \text { faktor } & \text { eksternal } \\ \text { yang memengaruhi } & \text { belajar } & \text { dapat }\end{array}$ digolongkan menjadi dua golongan, yaitu faktor lingkungan sosial dan faktor lingkungan nonsosial.

\section{Faktor Lingkungan}

a. Lingkungan sosial masyarakat. Kondisi lingkungan masyarakat tempat tinggal siswa akan memengaruhi belajar siswa. Lingkungan siswa yang kumuh, banyak pengangguran dan anak telantar juga dapat memengaruhi aktivitas belajar siswa, paling tidak siswa kesulitan ketika memerlukan teman belajar, diskusi, atau meminjam alat-alat belajar yang kebetulan belum dimilikinya.

\section{b. Lingkungan sosial keluarga.}

Lingkungan ini sangat memengaruhi kegiatan belajar. Ketegangan keluarga, sifat-sifat orangtua, demografi keluarga (letak rumah), pengelolaan keluarga, semuanya dapat memberi dampak terhadap aktivitas belajar siswa. Hubungan antara anggota keluarga, orangtua, anak, kakak, atau adik yang harmonis akan membantu siswa melakukan aktivitas belajar dengan baik.

\section{c. Lingkungan sosial sekolah}

Seperti guru, administrasi, dan teman-teman sekelas dapat memengaruhi proses belajar seorang siswa. Hubungan yang harmonis antara ketiganya dapat menjadi motivasi bagi siswa untuk belajar lebih baik di sekolah. maka para pendidik, orangtua, dan guru perlu memerhatikan dan memahami bakat yang dimiliki oleh anaknya atau peserta didiknya

\section{Lingkungan nonsosial}

Faktor faktor yang termasuk lingkungan nonsosial adalah:

\section{a. Faktor materi pelajaran}

Faktor ini hendaknya disesuaikan dengan usia perkembangan siswa, begitu juga dengan metode mengajar guru, disesuaikan dengan kondisi perkembangan siswa. Karena itu, agar guru dapat memberikan kontribusi yang positif terhadap aktivitas belajar siswa, maka guru harus menguasai materi pelajaran dan berbagai metode mengajar yang dapat diterapkan sesuai dengan kondisi siswa. 


\section{b. Faktor instrumental,}

Faktor instrumentalyaitu perangkat belajar yang dapat digolongkan dua macam. Pertama, hardware, seperti gedung sekolah, alat-alat belajar, fasilitas belajar, lapangan olahraga dan lain sebagainya. Kedua, software, seperti kurikulum sekolah, peraturan-peraturan sekolah, buku panduan, silabus, dan lain sebagainya.

\section{4. Motivasi}

Dalam proses pemerolehan bahasa, salah satu aspek yang berperan penting adalah motivasi. Adapun pengertian motivasi menurut Makmun (2007: 37) adalah suatu kekuatan (power) atau tenaga (forces) atau daya (energy) atau suatu keadaan yang kompleks (a complex state) dan kesiapsediaan (prepatory set) dalam diri individu (organisme) untuk bergerak (to move, motion, motive) ke arah tujuan tertentu, baik disadari maupun tidak disadari.

Motivasi adalah salah satu faktor yang memberikan kontribusi pada keberhasilan pembelajaran bahasa kedua. Longman Dictionary of Applied Linguistics (1985) mendefinisikan motivasi sebagai faktor yang menentukan keinginan (desire) seseorang untuk melakukan sesuatu. Pengertian Motivasi Menurut Para Ahli adalah sebagai berikut:

1. Cropley, (1985) Motivasi dapat dijelaskan sebagai "tujuan yang ingin dicapai melaluiperilaku tertentu".

2. Wlodkowski (1985) menjelaskan motivasi sebagai suatu kondisi yang menyebabkan atau menimbulkan perilaku tertentu, dan yang memberi arah dan ketahanan (persistence) pada tingkah laku tersebut. Motivasi instrumental adalah keinginan belajar suatu bahasa karena bahasa itu berguna untuk tujuan 'instrumental' tertentu seperti mendapatkan pekerjaan, membaca koran, atau lulus tes. Sedangkan motivasi integratif adalah keinginan belajar bahasa agar bisa berkomunikasi dengan orang dari budaya lain yang menggunakan bahasa itu.

\subsection{Metode Mengajar}

Dari segi bahasa metode berasal dari dua kata, yaitu meta dan hodos. Meta berarti 'melalui' dan hodos berarti 'jalan' atau 'jalan'. Dengan demikian metode adalah dapat berarti cara atau jalan yang harus dilalui untuk mencapai suatu tujuan. Adapun kata 'metodologi' berasal dari kata 'metoda' dan 'logi'. Logi berasal dari bahasa Yunani logos yang berarti akal atau ilmu. Jadi metodologi artinya ilmu tentang jalan atau cara yang harus dilalui untuk mencapai suatu tujuan.

\section{5. 1. Macam- macam Metode Mengajar dan Penggunaannya \\ 1. Metode ceramah \\ Metode ceramah adalah sebuah bentuk} interaksi melalui penerangan dan penuturan secara lisan oleh seorang guru terhadap kelasnya. Dalam pelaksanaan ceramah untuk menjelaskan urainnya, guru dapat menggunakan alat-alat bantu, seperti gambar- gambar.

\section{Metode Tanya jawab}

Metode tanya jawab ialah cara penyajian pelajaran dalam bentuk pertanyaan yang harus dijawab, terutama dari guru ke siswa dan begitu juga sebaliknya.

\section{Metode diskusi}

Muhibbin Syah (2000), mendefinisikan bahwa metode diskusi adalah metode mengajar yang sangat erat hubungannya dengan memecahkan masalah (problem solving).

4.Metode pemberian tugas belajar (resitasi)

Metode pemberian tugas adalah suatu cara dalam proses belajar mengajar di mana guru memberi tugas tertentu dan murid mengerjakannya, kemudian tugas tersebut dipertanggung jawabkan kepada guru.

\section{Metode demontrasi dan eksperimen}

Metode Demostrasi atau praktik adalah metode mengajar yang menggunakan peragaan untuk memperjelas suatu pengertian atau untuk memperlihatkan bagaimana melakukan sesuatu kepada anak didik.

6. Metode sosiodrama dan bermain peran

Metode ini menampilkan symbolsimbol atau peralatan yang menggantikan proses kejadian atau benda yang sebenarnya. Metode ini adalah suatu cara penguasaan 
bahan pelajaran melalui pengembangan dan penghayatan anak didik.

\section{Metode karyawisata}

Menurut Djamarah (2000:105), pada saat belajar mengajar siswa perlu diajak ke luar sekolah, untuk meninjau tempat tertentu atau obyek yang lain.

\section{Metode Test}

Ialah metode mengajar dengan jalan memberikan tes kepada anak - anak untuk mengetahuikemampuan anak dalam suatu kegiatan pelajaran.

\section{Metode Drill \\ Metode mengajar dengan mempergunakan latihan-latihan secara intensif dan berulang- ulang adalah memberikan latihan tertulis kepada anak.}

\section{Metode Infiltrasi}

Metode ini disebut juga metode susupan, selipan maksudnya antipati atau jiwa ajaran tertentu diselipkan kedalam sesuatu.

\section{6. Mata Kuliah Dasar Umum Bahasa Inggris dan Kebutuhan Mahasiswa}

Menurut Ahmad (1999 dan 2002)

tujuan pengajaran bahasa Inggris di perguruan tinggi (non jurusan bahasa Inggris) adalah untuk memahami perkuliahan dalam bahasa Inggris, untuk membaca buku teks yang ditulis dalam bahasa Inggis, dan gabungan dari keduanya. Tujuan pengajaran ini selaras dengan tujuan yang dikemukakan oleh Munby (1978) McDonough (1984), Kennedy and Bolitho (1985). Mereka semuanya menyatakan bahwa tujuan pengajaran Bahasa Inggris di perguruan tinggi adalah untuk mendukung kegiatan akademis mahasiswa yang mereka sebut dengan istilah English for Academic Purposes.

Tujuan pengajaran bahasa Inggris di perguruan tinggi yang dikemukakan oleh kelima para ahli bahasa tersebut diatas, semuanya dalam lingkup yang sama, yaitu ruang lingkup akademis atau tujuan untuk memenuhi kebutuhan mahasiswa selama mereka mengikuti perkuliahan di perguruan tinggi.

\section{Metodologi Penelitian}

Metode yang digunakan dalam penelitian ini adalah penelitian kuantitatif yang bersifat eksplanasi dengan pendekatan survei bersifat eksplanasi karena bertujuan untuk menjelaskan hubungan antara satu variabel dengan variabel yang lain (Sugiyono, 2005:11). Penelitian ini menggunakan pendekatan survei "yaitu penelitian yang dilakukan pada populasi besar/kecil, tetapi data yang dipelajari adalah data dari sampel yang diambil dari populasi tersebut sehingga ditemukan hubungan antara variabel" (Kerlinger, dalam Sugiyono, 2004:7). Penelitian ini bertujuan untuk menentukan ada tidaknya pengaruh anatara sikap, motivasi dan metode dosen mengajar terhadap hasil belajar Bahasa Inggris sebagai mata kuliah MKDUdi Politeknik Negeri Jember.

Dalam penelitian ini, sampel yang diambil adalah $25 \%$ dari jumlah populasi yang telah disebutkan di atas dengan perinciannya yaitu sebanyak 80 mahasiswa Politeknik Negeri Jember angkatan 20132014 dari berbagai jurusan atau program studi selain program studi Bahasa Inggris.

Alat pengumpulan data yang digunakan adalah angket atau daftar pertanyaan. Angket tersebut menggunakan skala Likert yaitu yang digunakan untuk mengukur sikap, pendapat dan persepsi seseorang atau sekelompok orang-orang. Dengan skala Likert variabel yang diukur dijabarkan menjadi indikator variabel, jawaban setiap item pertanyaan untuk keperluan analisis kuantitatif diberi skor Riduwan (2004:48). Skor masing-masing adalah sebagai berikut:

a) Skor 4 untuk jawaban Sering Sekali (SS)

b) Skor 3 untuk jawaban Sering (S)

c) Skor 2 untuk jawaban Jarang(J)

d) Skor untuk jawaban Tidak Pernah (TD)

\section{Teknik Presentase}

Untuk mengetahui bagaimana pengaruh sikap, motivasi dan metode mengajar terhadap evaluasi hasl belajar MKDU Bahasa Inggris mahasiswa, penelitian ini ingin mengetahui tingkat prosentase jawaban responden dengan menggunakan rumus: 
$\mathrm{N}$

Keterangan

$\begin{array}{ll}\mathrm{P} & \text { : Persentase yang dicari } \\ \mathrm{F} & \text { : Frekuensi jawaban } \\ \mathrm{N} & \text { : Jumlah responden } \\ 100 \% & \text { : Bilangan tetap }\end{array}$

\section{Regresi Sederhana}

Untuk menganalisis data yang ada digunakan teknik analisis kuantitatif, kemudian untuk mengetahui hubungan antara sikap, motivasi belajar mahasiswa, dan metode dosen mengajar terhadap hasil belajar mahasiswa dilakukan denganmetode regresi sederhana dengan persamaan sebagai berikut:

$$
\text { a. Variabel Sikap }
$$

Keterangan:

$\mathrm{Y}=$ Hasil belajar mahasiswa

$\mathrm{X} 1=$ Sikap belajar siswa

a $\quad=$ Konstanta

$\mathrm{b} \quad=$ koefisien regresi

\section{b. Variabel Motivasi}

Keterangan:

$$
\mathrm{Y}=\mathrm{a}+\mathrm{bX}
$$

$\mathrm{Y} \quad=$ Hasil belajar mahasiswa

$\mathrm{X} 2=$ Motivasi belajar siswa

a $\quad=$ Konstanta

$\mathrm{b} \quad=$ Koefisien regresi

\section{c. Variabel metode mengajar}

$$
\mathrm{Y}=\mathrm{a}+\mathrm{bX}
$$

Keterangan :

$\begin{array}{ll}\mathrm{Y} & =\text { Hasil belajar mahasiswa } \\ \mathrm{X} 2 & =\text { Metode Mengajar } \\ \mathrm{a} & =\text { Konstanta } \\ \mathrm{b} & =\text { Koefisien regresi } \\ & \text { Sebelum dilakukan pengujian }\end{array}$ hipotesis terlebuh dahuu dilakukan uji asumsi klasik yaitu : Uji Normalitas, uji multikolinieritas sebagai berikut:

\section{a. Uji Normalitas}

Adalah uji yang digunakan untuk mengetahui apakah variabel independent dan variabel dependent dari suatu regresi memiliki distribusi data yang normal atau mendekati normal uji dilakukan dengan grafik yang diperoleh dari pengolahan data.

\section{b. Uji Multikolinieritas}

Adalah uji yang digunakan untuk mengetahui apakah pada suatu model regresi linier berganda terdapat korelasi antar variabel independent. Uji ini dilakukan dengan melihat nilai VIF (variance inflation factor) dan koefiensi korelasi antar variabel bebas. Kriteria yang digunakan yakni (joko Sulistyo 2010:56). Jika nilai VIF disekitar angka 1 atau memiliki toleransi mendekati 1 , maka dikatakan tidak terdapat masalah multikolinieritas.

\section{9. Pengujian Hipotesis}

Selanjutnya untuk membuktikan hipotesis penelitian digunakan uji statistik dengan criteria pengujian sebagai berikut:

a. Uji t

Uji t digunakan untuk mengetahui pengaruh variabel independent secara masing-masing (parsial) terhadap variabel dependent

a) Jika $\mathrm{t}$ hitung $\geq \mathrm{t}$ tabel maka Ho ditolak dan Ha diterima

Berarti hipotesis diterima, maksudnya variabel X1, X2, X3 berpengaruh secara parsial terhadap variabel Y.

b) Jika $\mathrm{t}$ hitung $\leq \mathrm{t}$ tabel maka Ho diterima dan Ha ditolak

Berarti hipotesis ditolak, maksudnya variabel $\mathrm{X} 1, \mathrm{X} 2, \mathrm{X} 3$ tidak berpengaruh secara parsial terhadap variabel Y.

\section{b. Uji F}

Uji $\mathrm{F}$ digunakan untuk mengetahui pengaruh variabel independent secara simultan (bersama-sama) terhadap variabel dependent.

a) Jika F hitung $\geq \mathrm{F}$ tabel maka Ho ditolak dan Ha diterima

Berarti variabel independent secara bersama-sama (simultan) berpengaruh terhadap variabel independent.

b) Jika $\mathrm{F}$ hitung $\leq \mathrm{F}$ tabel maka Ho diterima dan Ha ditolak

Berarti variabel independent secara bersama-sama (simultan) tidak berpengaruh terhadap variabel independent.

4. Hasil

4.1. Deskriptif Data

4.1.1. Analisis Deskriptif Variabel Sikap (X1) 
Sikap belajar mahasiswa dalam penelitian ini dikumpulkan dengan menggunakan 5 indikator yaitu sikap kepada dosen, indikator tujuan belajar, indikator pemahaman mahasiswa dalam materi pelajaran, indikator kegiatan siswa dalam proses belajar mengajar, dan indikator mengerjakan tugas yang diberikan dosen. Dari 5 indikator tersebut kemudian dikembangkan menjadi 12 item pernyataan yang disebarkan kepada 80 responden dengan hasil sebagai berikut : untuk alternatif jawaban Sering Sekali (SS) memperoleh frequensi 9 atau $1 \%$, untuk alternatif jawaban Sering (S) memperoleh frequensi 114 atau $12 \%$, untuk alternatif jawaban Jarang (J) memperoleh frequensi 299 atau 31\%, untuk alternatif jawaban Tidak Pernah (TP) memperoleh frequensi 538 atau $56 \%$

\subsubsection{Analisis Deskriptif Variabel Motivasi (X2)}

Motivasi belajar mahasiswa dalam penelitian ini dikumpulkan dengan menggunakan 8 indikator yaitu faktor eksternal indikator tekun menghadapai tugas, indikator ulet menghadapi kesulitan, indikator menunjukkan minat terhadap MKDU Bahasa Inggris, indikator bekerja dan berusaha mandiri dan faktor eksternal yakni pemberian hadiah, indikator pujian dan indikator memberi angka. Dari tujuh indikator tersebut kemudian dikembangkan menjadi 19 item pernyataan yang disebarkan kepada 80 responden dengan hasil sebagai berikut: Untuk alternatif jawaban Sering sekali (SS) memperole frequensi 10 atau $1 \%$, untuk alternatif jawaban Sering (S) memperoleh frequensi 136 atau 9\%, untuk alternatif jawaban Jarang (J) memperoleh frequensi 401 atau 26\%, untuk alternatif jawaban Tidak Pernah (TP) memperoleh frequensi 973 atau $64 \%$.

\subsubsection{Analisis Deskriptif Variabel Metode Mengajar (X3)}

Metode mengajar dosen dalam penelitian ini dikumpulkan dengan menggunakan 3 indikator yaitu indikator menekankan pencapaian kompetensi, indikator penyampaian materi menggunakan metode yang bervariasi, indikator fasilitasyang menunjang pembelajaran. Dari 3 indikator tersebut kemudian dikembangakan menjadi 9 item pernyataan yang disebarkan kepada 80 responden dengan hasil sebagai berikut : Untuk alternatif jawaban Sering sekali (SS) memperole frequensi 8 atau $1 \%$, untuk alternatif jawaban Sering (S) memperoleh frequensi 73 atau $10 \%$, untuk alternatif jawaban Jarang (J) memperoleh frequensi 197 atau 27\%, untuk alternatif jawaban Tidak Pernah (TP) memperoleh frequensi 442 atau $61 \%$.

\subsection{Analisis Uji Normalitas}

Deteksi normalitas dilihat dengan menggunakan grafik normal P-P Plot of regression standarized residual. Uji normalitas adalah uji yang digunakan untuk mengetahui apakah variabel independent dari suatu regresi memiliki distribusi data yang normal atau mendekati normal. Uji dilakukan dengan grafik yang diperoleh dari pengolahan data. Dasar pengambilan keputusan adalah, jika terdapat normalitas, amaka residual akan terdistribusi secara normal. Dari hasil uji normalitas yang dilakukan, disimpulkan bahwa sampel tersebut distribusi normal sehingga dapat diuji menggunakan statistik parametik.

\subsubsection{Uji Multikolinearitas}

Uji multikolinearitas dengan menggunakan VIF paling banyak dilakukan dalam penelitian di Indonesia. Asumsi multikolinearitas terpenuhi jika dengan melihat nilai VIF (variance inflation fa korelasi antar variabel factor) dan koefisien korelasi antar variabel bebas. Pada uji multikolinarietas yang dilakukan dalam penelitian ini terdapat variabel sikap yang mempunyai tolerance sebesar 0,850 sedangkan nilai VIF 1,176. Variabel motivasi mempunyai tolerance sebesar 0,674 , sedangkan nilai VIF 1483. Variabel metode mengajar mempunyai nilai tolerance sebesar 0,662, sedangkan nilai VIF 1,510. Maka tidak terdapat gangguan multikolinearitas pada penelitian ini. Sehingga penelitian ini bebas dan layak digunakan. Karena tolerance dibawah 1 VIF diatas 1 maka dapat disimpilkan asumsi multikolinearitas terpenuhi yang berarti tidak terdapat hubungan antara variabel bebas. 


\subsection{Analisis Pengaruh Sikap, Motivasi dan Metode Mengajar Terhadap Hasil Belajar MKDU Bahasa Inggris}

Guna mengetahui pengaruh sikap, motivasi dan metode mengajar terhadap hasil belajar Mahasiswa pada MKDU Bahasa Inggris, maka dilakukan analisis data dengan analisis regresi sederhana dan hasilnya dihasilkan dari Output SPSS versi 17 berikut:

\subsubsection{Regresi Sederhana}

\section{a. Variabel Sikap}

Dari hasil pengolahan data melalui SPSS 17 didapat data sebagai berikut:

$\mathrm{Y}=50.123+1.122 \mathrm{X}$, artinya setiap terjadi penambahan satu-satuan $\mathrm{X}$ (variabel sikap naik satu-satuan), maka terjadi kenaikan Y sebesar 1.122 (variabel hasil belajar naik 1.122)

\section{b. Variabel Motivasi}

Dari hasil pengolahan data melalui SPSS 17 didapat data sebagai berikut:

$\mathrm{Y}=48.501+0.758 \mathrm{X}$, artinya setiap terjadi penambahan satu-satuan $\mathrm{X}$ (variabel sikap naik satu-satuan), maka terjadi kenaikan Y sebesar 0.758 (variabel hasil belajar naik 0.758 )

\section{c. Variabel Metode Mengajar}

Dari hasil pengolahan data melalui SPSS 17 didapat data sebagai berikut:

$\mathrm{Y}=53.139+1.348 \mathrm{X}$, artinya setiap terjadi penambahan satu-satuan X (variabel sikap naik satu-satuan), maka terjadi kenaikan Y sebesar 1.348 (variabel hasil belajar naik 1.348)

\subsubsection{Pengujian Hipotesis}

\section{Uji t (secara parsial)}

Ha diterima apabila ada pengaruh Ho ditolak apabila tidak ada pengaruh. Pengujian hipotesis ini dengan menggunakan uji t dengan kriteria:

Jika t hitung $>\mathrm{t}$ tabel maka Ho ditolak dan Ha diterima

Jika $\mathrm{t}$ hitung $<\mathrm{t}$ tabel maka Ho diterima dan Ha ditolak

\section{a. Variabel Sikap}

Dari tabel didapatkan nilai t hitung $=8.165$, Diketahui $\mathrm{n}=80$ maka df $=\mathrm{n}-\mathrm{k}, 80$ $3=77$. Dibandingkan dengan nilai $t$ tabel pada df $=77$ dengan taraf signifikansi $5 \%$ maka didapatkan nilai $\mathrm{t}$ tabel $=1,991$.
Kemudian dibandingkan antara t hitung dan $\mathrm{t}$ tabel didapatkan $\mathrm{t}$ hitung $(8.165)>\mathrm{t}$ tabel $(1,991)$.

Dengan demikian karna $\mathrm{t}$ hitung $>\mathrm{t}$ tabel maka Ho ditolak dan Ha diterima yaitu ada pengaruh antara sikap belajar terhadap hasil belajar mahasiswa pada MKDU Bahasa Inggris di Politeknik Negeri Jember.

\section{b. Variabel Motivasi}

Dari tabel didapatkan nilai t hitung $=8.037$, Diketahui $\mathrm{n}=80$ maka $\mathrm{df}=\mathrm{n}-\mathrm{k}, 80$ $3=77$. Dibandingkan dengan nilai $\mathrm{t}$ tabel pada df $=77$ dengan taraf signifikansi $5 \%$ maka didapatkan nilai $\mathrm{t}$ tabel $=1,991$. Kemudian dibandingkan antara t hitung dan $\mathrm{t}$ tabel didapatkan $\mathrm{t}$ hitung $(8.037)>\mathrm{t}$ tabel $(1,991)$.

Dengan demikian karna $\mathrm{t}$ hitung $>\mathrm{t}$ tabel maka Ho ditolak dan Ha diterima yaitu ada pengaruh antara motivasi belajar terhadap hasil belajar mahasiswa pada MKDU Bahasa Inggris di Politeknik Negeri Jember.

\section{c. Variabel Metode Mengajar}

Dari tabel didapatkan nilai t hitung $=5.630$, Diketahui $\mathrm{n}=80$ maka $\mathrm{df}=\mathrm{n}-\mathrm{k}, 80$ $3=77$. Dibandingkan dengan nilai $\mathrm{t}$ tabel pada $\mathrm{df}=77$ dengan taraf signifikansi $5 \%$ maka didapatkan nilai $\mathrm{t}$ tabel $=1,991$. Kemudian dibandingkan antara t hitung dan $\mathrm{t}$ tabel didapatkan $\mathrm{t}$ hitung (5.630) $>\mathrm{t}$ tabel $(1,991)$.

Dengan demikian karna $\mathrm{t}$ hitung $>\mathrm{t}$ tabel maka Ho ditolak dan Ha diterima yaitu ada pengaruh antara metode mengajar terhadap hasil belajar mahasiswa pada MKDU Bahasa Inggris di Politeknik Negeri Jember.

\section{Uji F (Secara Simultan)}

Berdasarkan dari perhitungan dengan menggunakan SPSS Versi 17 diperoleh $\mathrm{F}$ hitung adalah sebesar 58.134 dengan signifikan sebesar 0.000 atau lebih besar dari F tabel adalah sebesar 2, 72. Karena $\mathrm{F}$ hitung lebih besar dari $\mathrm{F}$ tabel maka Ha diterima, artinya sikap, motivasi dan metode mengajar secara bersama-sama berpengaruh positif terhadap hasil belajar mahasiswa.

\section{Uji Signifikansi \\ a. Variabel Sikap}


Berdasarkan hasil SPSS 17 didapatkan nilai signifikansi sebesar 0.000. Hal ini menunjukkan bahwa signifikansi $0,000<0,05$ dengan demikian pengaruh sikap belajar mahasiswa terhadap hasil belajar mahasiswa dikatakan signifikan.

\section{b. Variabel Motivasi}

Berdasarkan hasil SPSS 17 didapatkan nilai signifikansi sebesar 0.000. Hal ini menunjukkan bahwa signifikansi $0,000<0,05$ dengan demikian pengaruh motivasi belajar mahasiswa terhadap hasil belajar mahasiswa dikatakan signifikan.

\section{c. Variabel Metode Mengajar}

Berdasarkan hasil SPSS 17 didapatkan nilai signifikansi sebesar 0.000 . Hal ini menunjukkan bahwa signifikansi $0,000<0,05$ dengan demikian pengaruh metode mengajar dosen terhadap hasil belajar mahasiswa dikatakan signifikan.

\section{Koefisien Determinasi}

Koefisien korelasi adjusted $\mathrm{R}$ square untuk mengetahui apakah dari ketiga variabel bebas (X1, X2, X3) berpengaruh secara siultan (bersama-sama) terhadap variabel terkait (Y). Dari pengolahan data melalui SPSS 17 didapat data bahwa dari hasil perhitungan regresi adjusted $\mathrm{R}$ square adalah sebesar 0,692 hal ini menunjukkan bahwa ketiga variabel independen tersebut secara bersama-sama mampu memberikan sumbangan terhadap variabel dependen sebesar $69,2 \%$.

\section{Pembahasan}

Dari hasil penelitian yang penulis lakukan maka dapat diketahui bahwa sikap belajar mahasiswa dapat mempengaruhi hasil belajar mahasiswa, ini dapat dilihat pada uji t yakni t hitung $(8.165)>\mathrm{t}$ tabel $(1,991)$ dan dilakukan uji signifikan sebesar $0,000<0,05$. Hal ini sesuai dengan pernyataan (Slameto, 2003:188) faktor yang mempengaruhi hasil belajar adalah sikap, sikap merupakan sesuatu yang dipelajari, dan sikap menentukan bagaimana individu bereaksi terhadap situasi serta menentukan bagaimana individu dalam kehidupan.

Untuk mengetahui pengaruh motivasi siswa terhadap hasil belajar secara parsial dilihat pada uji $t$ yakni $t$ hitung $(8.037)>\mathrm{t}$ tabel $(1,991)$ dan dilakukan secara signifikan sebesar $0,000<0,05$. Dengan demikian hal ini sesuai dengan pernyataan (Sardiman, 2003:73) Motivasi belajar dorongan yang ada dalam diri siswa, motivasi belajar pada diri siswa perlu diperkuat terus menerus. Dengan tujuan agar memiliki motivasi belajar yang kuat, sehingga hasil belajar yang diaraihnya optimal.

Sedangkan pengaruh metode mengajar juga berpengaruh terhadap hasil belajar, dapat dilihat dari uji t yakni t hitung (5.630) > t tabel $(1,991)$ dan secara signifikan sebesar $0,000<0,05$. Dengan demikian hal ini sesuai dengan pernyataan (Slameto, 2003:76) bahwa metode mengajar suatu cara yang harus dilalui dalam mengajar apabila metode yang digunakan baik maka dapat meningkatkan hasil belajar mahasiswa.

\section{Kesimpulan dan Saran}

Berdasarkan analisis data mengenai pengaruh sikap, motivasi dan metode mengajar terhadap hasil belajar mahasiswa pada MKDU Bahasa Inggris di Politeknik Negeri Jember yang diolah melalui angket dan hasil study mahasiswa, maka dapat diambil kesimpulan:

1. Adanya pengaruh positif signifikan sikap belajar mahasiswa pada MKDU Bahasa Inggris di Politeknik Negeri Jember.

2. Adanya pengaruh positif signifikan motivasi belajar terhadap hasil belajar mahasiswa pada MKDU Bahasa Inggris di Politeknik Negeri Jember.

3. Adanya pengaruh positif signifikan metode mengajarterhadap hasil belajar mahasiswa pada MKDU Bahasa Inggris di Politeknik Negeri Jember.

Beberapa saran pada pihak-pihak terkait dengan penelitian ini yang ingin peneliti sampaikan adalah:

1. Bagi lembaga Politeknik Negeri Jember Untuk mendapatkan hasil belajar yang tinggi, maka perlu memeperhatikan sikap belajar mahasiswa, motivasi dan metode mengajar. Untuk meningkatkan sikap belajar mahasiswa, motivasi belajar mahasiswa dan metode mengajar dapat dilakukan dengan memantapkan tujuan belajar sebagai salah satu faktor penunjang kesuksesan.

2. Bagi Pengajar/Dosen 
Perlu melakukan berbagai upaya guna meningkatkan hasil belajar mahasiswa yakni dengan melihat sikap belajar mahasiswa, selalu mendorong dan membangkitkan motivasi dan keinginan yang kuat belajar mahasiswa, dan meningkatkan metode mengajar khususnya mata MKDU Bahasa Inggris.

3. Bagi Peneliti selanjutnya

Agar meneliti lebih lanjut variabel lainnya yang dapat mempengaruhi hasil belajar mahasiswa, seperti sarana dan prasarana, lingkungan kampus Politeknik Negeri Jember, tingkat ekonomi mahasiswa dan lain sebagainya.

DAFTAR PUSTAKA

Ali, Muhammad. 1987. Penelitian

Pendidikan: Prosedur dan

Strategi, Bandung: PT. Angkasa

Arikunto, Suharsimi. 2002. Prosedur

Penelitian Suatu Pendekatan

Praktek.Jakarta: PT Adi

Mahasatya.

Brown, H. D. 2000. Principles of Language

Learning and Teaching. Prentice Hall, inc. Englewood Clifffs: New Jersey.

Kachru, B.B. 1986. The Power and Politics of English. World Englishes, 1986, 2(3), 121-40

Makmun, Abin Syamsuddin. (2007). Psikologi Kependidikan: Perangkat Sistem Pengajaran Modul. Bandung: PT Remaja RosdaKarya.

Mc Donough, J. I. 1984, ESP in Perspective: A Practical Guide. London: Hazell Watson and Viney Limited.

Sofendi, 2003, ELT vs ESP. Makalah disajikan dalam forum HEDS di niversitas Jambi pada tanggal 6 sampai dengan 8 Mei 2003

Suryabrata Sumadi . Psikology Pendidikan. Jakarta : Raja Grafindo Persada . 2004

Syah Muhibbin . Psikologi Pelajar . Jakarta : Raja Grafindo Persada . 2003 